\author{
Євген Причепій Yevhen Prychepii \\ доктор філософських наук, професор \\ провідний науковий співробітник \\ відділ культурної антропології \\ Інститут культурології \\ НАМ України \\ Doctor of Philosophy, professor \\ leading researcher \\ Department of Cultural Anthropology \\ Institute of Cultural Research, \\ National Academy of Arts of Ukraine
}

sharapann@ukr.net orcid.org/0000-0002-5363-1004

\title{
СТРУКТУРНИЙ МЕТОД ДОСЛІДЖЕННЯ СЕМАНТИКИ ГЕОМЕТРИЧНИХ ОРНАМЕНТІВ
}

\author{
Structural RESEARCH METHOD \\ OF SEMANTICS OF GEOMETRICAL ORNAMENTS
}

\begin{abstract}
Анотація. Спростовується теза, згідно з якою семантика геометричних орнаментів втрачена. Автор пропонує застосовувати при аналізі цих орнаментів структури, притаманні архаїчній символіці. В статті виділено тричленну структуру Богині в древній символіці і показано відображення цієї структури та її варіантів у геометричних орнаментах жіночих сорочок Поділля. 3 дослідження випливає, що геометричний орнамент зберіг свою семантику, і в неї можна проникнути, користуючись структурами первісних міфологічних уявлень. Ключові слова: структури, геометричний орнамент, семантика орнаменту.
\end{abstract}

Постановка проблеми. Під «геометричним орнаментом» автор розуміє орнамент, утворений з геометричних фігур (кругів, овалів, квадратів, ромбів, трикутників, меандрів та ін.), який був поширений в архаїчній символіці (на археологічних артефактах) і в традиційній народній культурі. Цим орнаментам, на нашу думку, властиві усталені правила формування на відміну від орнаментів, які довільно творяться сучасними художниками чи математиками. Дослідники виділяють два основних аспекти орнаментів: семантичний (їнє смислове значення), та естетичний (функція оздоблення і прикрашання речей). Щодо естетичного аспекту серед дослідників принципових розбіжностей немає. Його визнають всі. Щодо семантики тривають дискусії, які зумовлені тим, що відсутній надійний метод, який дозволив би проникнути в неї.

Останні дослідження та публікації. Орнаменти досліджують археологи, етнографи та мистецтвознавці. Кожен з цих підходів має свою специфіку. Археологи (М. Гімбутас [5], А. Голан [1] та ін.), які вивчають архаїчні орнаменти, схильні вбачати в них певні смислові навантаження і намагаються дати їм інтерпретацію. Етнографи цікавляться традиційними народними орнаментами. Вони досліджують види і будову орнаментів, географічні ареали їх поширення, класифікують їх, намагаються зрозуміти семантику, але остання проблема знаходиться на периферії їх інтересів. I це зрозуміло, оскільки семантика орнаментів втратила свою роль у свідомості їх носіїв (сільського населення), то вона не так і важлива для етнографів. Серед них поширена думка, що сучасні геометричні орнаменти втратили свою семантику, тому вони досить скептично ставляться до спроб їх інтерпретації. Так, відома дослідниця української народної вишивки Т. Кара-Васильєва відзначає, що "геометричний орнамент сягає глибини тисячоліть, пов’язаний $з$ естетичними, технологічними, символічними факторами. В процесі історичного розвитку його давня семантика і оберегове значення були втрачені, зруйнована цілісна знаково-магічна система... Тому сьогодні важко підтвердити чи спростувати семантику орнаментальних мотивів геометричного орнаменту, тим більше йти шляхом їх розшифровки» [2, с. 45].

Мистецтвознавці мають справу виключно 3 естетичним аспектом орнаментів, який, на перший погляд, не пересікається з семантичним аспектом, тому вони, як правило, не переймаються проблемою семантики.

Автор цієї розвідки виділяє ще один підхід до орнаментів, а саме культурологічний. Орнамент є феноменом культури. Орнамент доісторичної епохи відіграв важливу роль у становленні культури. В історичну добу він зазнав значних трансформацій, але, на нашу думку, зберіг свої стрижневі структури. Проникнення в ці структури важливе для розкриття семантики орнаментів і для розуміння їхньої ролі в становленні та еволюції культури.

Мета статті. Ми вважаємо, що геометричний орнамент українських народних сорочок (зокрема сорочок Поділля) зберіг свою семан- 


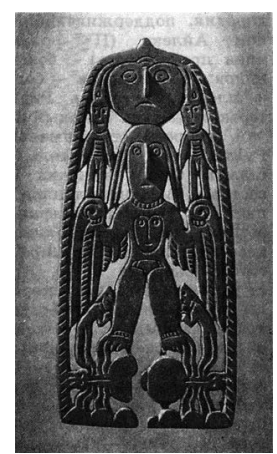

1

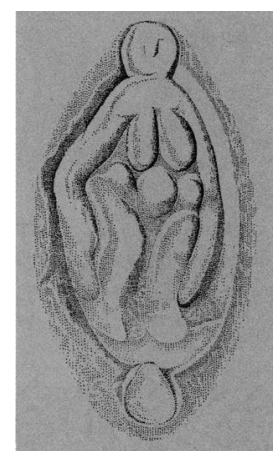

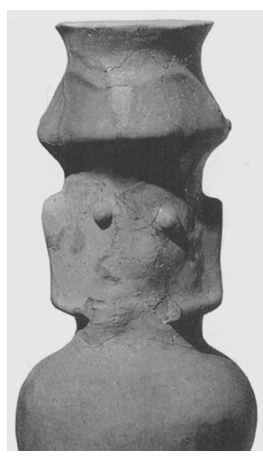

2

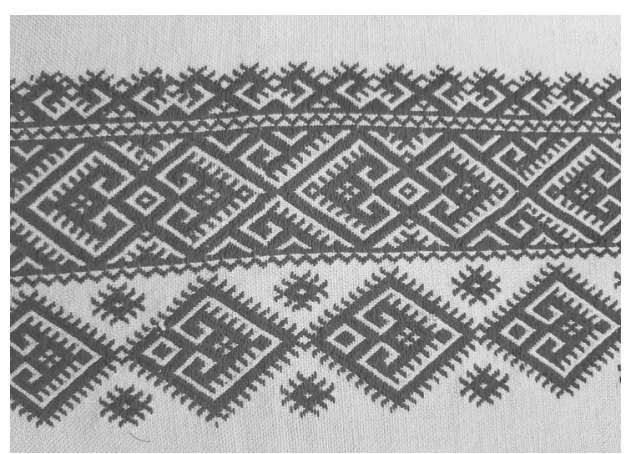

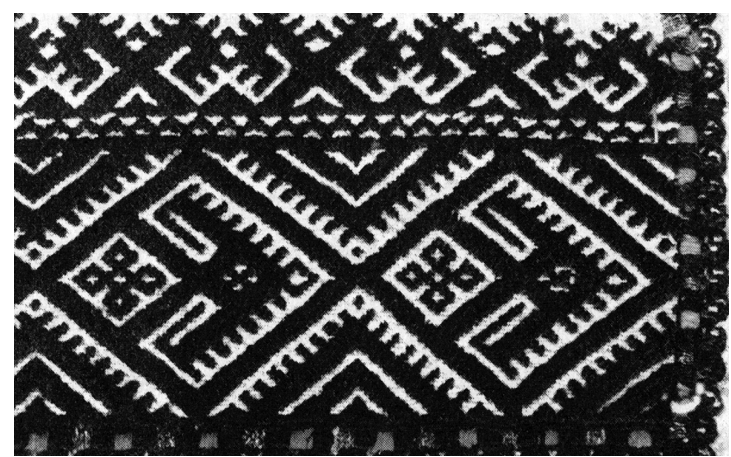

5,6
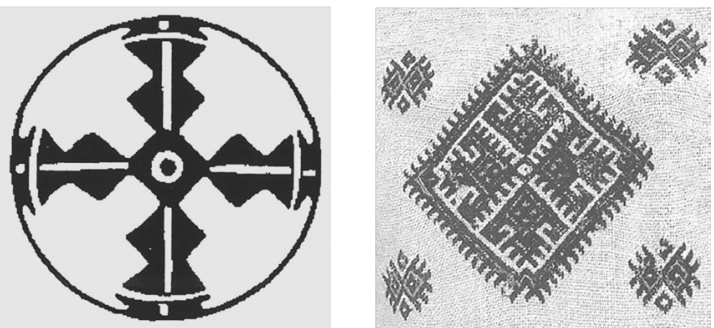

тику, і ключ для проникнення в неї лежить в первісному світогляді, в структурах, що були характерні для цього світогляду. Виходячи з цьог, мета cmammi полягає в тому, шоб розкрити структури первісного світогляду і показати, як на їх основі формувались орнаменти. Розкривши логіку формування орнаментів, ми проникнемо в їх суть, тобто розкриємо їхню семантику.

Виклад матеріалу дослідження. У світогляд первісних людей можна проникнути двома способами: через вивчення залишків їх матеріальної життєдіяльності (знарядь праці, жител та ін.) або через вивчення результатів їхньої духовної діяльності. Під останніми розуміються артефакти, на яких містяться образи (людей, тварин, небесних тіл), знаки різного роду (овали, ромби, трикутники, шеврони та ін.) та орнаменти (певним чином упорядковані знаки). Якщо залишки матеріальної діяльності опосередковано свідчать про духовний світ давніх людей, то в артефактах цей світ відобразився безпосередньо. Тому до них так привернута увага дослідників.

Ми досить умовно ділимо продукти духовної діяльності давніх людей на архаїчні символи (образи і знаки) та орнаменти. Орнаменти формувалися паралельно з архаїчною символікою. Їх можна вважати особливим видом упорядкування символів, оскільки символи входять як складовий елемент орнаментів. Так, відомі геометричні орнаменти з Мізина (18 тис. р. до н.е.) включають такі символи, як ромб, косий хрест, шеврон, меандр, свастика та ін., які можуть фігурувати і як окремі символи. Іншими словами, між архаїчною символікою та первісними орнаментами принципова різниця відсутня. Звідси випливає, що на первісні орнаменти поширюються ті ж правила конституювання, що були властиві й архаїчній символіці. Ми вважаємо, що первісний міфологічний світогляд був спільною основою для формування архаїчної символіки та первісних орнаментів.

тричленна структура Космосу і тіла Богині. На основі аналізу архаїчної символіки та орнаментів нам вдалося реконструювати деякі структури цієї міфології, яку ми умовно назвали праміфом. Основні ідеї праміфу полягають у наступному:

1. Космос давніх людей ділився на сім сфер: підземні води, підземелля, поверхня землі, сфера життя, піднебесся, сфера семи планет, сфера зоряного неба. Підземелля, сфера життя і сфера планет були сферами богинь (основними сферами), інші - богів. Останні вважались другорядними i, як правило, ігнорувались.

2. Втіленням Космосу була Велика Богиня, яка також ділилась на сім сфер, основними з яких були сідниці, живіт (пупець і груди) та голова (очі і рот). При цьому кожна 3 цих сфер Космосу в первісній свідомості розглядалась як втілення Дочки Богині. Так постали три богині, які втілювали три сфери Тіла Богині і три сфери Космосу. Цю трійку можна бачити на артефакті угро-фінської культури (мал. 1), на якому образ богині розпався на три вертикально розміщені богині. Отже, тричленна структура первісної символіки (і орнаментів) фігурувала водночас як три сфери Космосу, три частини Тіла Богині і як три богині.

Тричленна структура Космосу і Тіла Богині стала основою для формування ряду структур, які характерні для архаїчної символіки та орнаментів.

Богиня як тричленна структура. Богиня, як уже було зазначено, уявлялась дав- 
німи людьми як утворення з трьох «жіночих" сфер. Такий поділ і ліг в основу тричленної структури, яка часто зустрічається в архаїчній символіці та орнаментах. Тричленна структура означає, що артефакт, який складається із трьох жіночих сфер, або образ, утворений із трьох жіночих символів, передають Богиню-Космос. Отже, тричленна структура, елементи якої можна ідентифікувати як жіночі символи, являє собою образ БогиніКосмосу.

Таку структуру добре видно в формі цього горщика 3 Угорщини (мал. 2; 5 тис. років до н. е.). В ньому чітко виступає поділ артефакту на три частини, які символізують умовну голову, живіт і сідниці Богині-Космосу. Тепер розглянемо, як ця структура відображена в геометричних орнаментах жіночих сорочок.

Перш ніж переходити до цієї проблеми, варто зупинитись на семантиці такого символу, як ромб. В літературі є багато досить різноманітних інтерпретацій цього символу. Нам вдалось установити, що ромб (як і коло, овал, квадрат) позначає сферу або божество, і оскільки в первісному світогляді домінуючою була богиня, то ромб, як правило, позначав жіночі сфери або богинь. Звідси походить зображення голови у вигляді ромбу, ромби на животі, стегнах. У всіх цих випадках він позначає жіночі сфери або богинь. I коли ми бачимо на горщику з Малої Азї (мал. 3, 6-5 тис. до н.е.) образ, утворений за допомогою структури із трьох ромбів, ми маємо підставу вважати, що за ним приховується образ богині.

Подібний спосіб конституювання Богині 3 трьох жіночих символів (насамперед ромбів) закріпився і в геометричних орнаментах. Як приклад розглянемо цей орнамент жіночої сорочки 3 Поділля (мал. 4). Він складається з рядка ромбів. В кожному ромбові міститься фігурка, яка утворена з трьох менших ромбів. Ця фігура дещо нагадує антропоморфну істоту. Малий ромбик можна вважати за голову, дещо більший - за живіт і ще такий же ромбик між умовними ногами очевидно символізує сідниці. Фігура, отже, є тричленною структурою, утвореною з трьох ромбиків. Виходячи зі встановленого нами вище правила, її можна ідентифікувати як богиню. Додатково відмітимо, що зубці на умовних руках фігурки та інші моменти дали підставу для ідентифікації її як «богині-оленя» [4]. Отже, тричленна структура допомогла нам розпізнати за цим орнаментальним утворенням образ давньої богині.

Зазначимо, що структурний метод до аналізу орнаментів пробували застосувати ряд дослідників. Але їм не вдалось проникнути в семантику орнаментів, оскільки вони оперували лише формальними ознаками структур. Якщо виходити 3 формальних ознак, то маленький ромбик (голова) і дещо більші ромбики (живіт і сідниці) з розглянутого нами орнаменту не утворюють однієї структури. Вони утворюють тричленну структуру лише за умови, що всі три ромби розглядаються як рівноцінні члени і ми знаємо, що вони позначають жіночі сфери Космосу і Тіла Богині. Наш метод виділення структур в орнаментах опирається на знання структур архаїчної символіки, а також на знання семантики деяких базових символів, зокрема, ромбу.

Орнаментальні структури з двох богинь. В архаїчній символіці зустрічаються дещо неприродні утворення 3 двох жіночих фігурок. Це можуть бути фігурки 3 подвоєними головами і грудьми та спільними сідницями, або ж зображення двох лежачих жіночих фігурок, з'єднаних таким чином, що голови розташовані на протилежних кінцях, а тулуби (животи і груди) уміщені у спільному овалі (мал. 5, Франція, Дордонь, 25 тис. років до н.е.). $€$ різні інтерпретації цих дивних поєднань. Тут не місце детально розглядати суть цього феномену. Він розглянутий нами в статті [3, с. 89-101]. Зазначимо, що за ним, ймовірно, приховуються уявлення давніх людей про два сонця - літнє і зимове. Поділ циклу сонця на два півцикли зустрічається у таджиків та інших народів. В цьому поділі сонце фігурує водночас як одне і як поділене надвоє. До цього слід додати такий міфологічний момент. У праміфі сонце як одне з семи блукаючих світил давніх людей співвідносилось зі сферою життя і животом Богині (звідси походить вираз «сонячне сплетіння»). До сфери живота відносились і груди. В символіці грудьми іноді позначали сонце. Зрозуміло, що двійка грудей також могла вплинути на формування феномену двох сонць. А оскільки сонце в первісній символіці фігурувало як богиня, то двійка грудей чи два півцикли сонця могли бути підставою для формування здвоєного образу богині.

Два сонця могли стати поштовхом для поділу неба на літнє і зимове. Оскільки небо втілювала голова, то двоголові богині виражають поділ і єдність неба. (Таке поєднання, до речі, притаманне і двоголовому орлу, який насправді є орлицею. В нього також дві голови, що символізують дві половини неба, і двійка грудей, що символізують два сонця).

Зрештою для нас важить не так інтерпретація цього феномена, як сама наявність його в архаїчній символіці. Важливо те, що подібну структуру, яка передає здвоєних богинь, можна бачити в геометричних орнаментах подільських жіночих сорочок. Так, уставка цієї сорочки (мал. 6, с. Шарапанівка, Вінниччина) складається із верхньої вузької стрічки, середньої суцільної орнаментальної стрічки і нижньої стрічки, що складається з окремих візерунків. Орнамент верхньої стрічки не стосується нашої теми. Окремі візерунки нижньої стрічки утворені з ромбів, в яких розташовані образи богинь, які вже розглянуті нами на мал. 4. Нас у цій уставці цікавить суцільна орнаментальна стрічка, що розташована посередині. Вона складається з візерунків, утворених 3 двох з'єднаних ромбів. Усередині цих ромбів можна бачити двох богинь, 
подібних до богинь 3 нижніх ромбів. Кожна 3 них має свій ромбик-голову, свій ромбик-живіт і спільний ромбик-сідниці. Цей орнамент за структурою повторює розглянуту структуру зі здвоєних богинь архаїчної символіки. Характерно, що здвоєння підкреслено не тільки подвоєнням фігурок богинь, воно виражено і здвоєнням зовнішніх ромбів, у яких розміщені богині. Вони також фігурують і як одиниця (з'єднані в одне просторове тіло) і як двійка (як два ромби). Розглянуте дає нам підставу вважати, що цей орнамент зберіг структуру, яка притаманна архаїчній символіці.

Структура з чотирьох богинь, які пере дають об'ємний Космос. В архаїчній символіці важливе місце посідала структура, утворена 3 чотирьох богинь, розміщених по кругові. Вона утворилась з богинь первісного пантеону - Великої Богині і трійки Дочок, кожна 3 яких відповідала за одну з трьох сфер Космосу. Разом $з$ Матір'ю трійка складала четвірку. Четвірка богинь, розміщена по кругові, символізувала об'ємний Космос. Оскільки кожна з богинь була сімкою (ділилась на сімку сфер), то така структура набувала характеру двадцятивосьмичленної. Ця структура відігравала важливу роль у первісній міфології. Будучи структурою Космосу (складаючи його просторову архітектоніку), вона водночас виражала важливі часові інтервали - тривалість сидеричного циклу Місяця і фізіологічного циклу жінки-богині. Тому поєднання чотирьох богинь було таким популярним в архаїчній символіці.

Особливого поширення зображення четвірки богинь по кругові набуло в неоліті. На круглих (в тому числі й об'ємних) керамічних виробах було зручно розміщувати образи (символи) четвірки богинь. Прикладом такої структури в архаїчній символіці може бути цей артефакт 3 Малої Азії (мал. 7; 6 тис. до н. е.). Тут швидше за все на тарілці чи блюді зображені дещо схематичні жіночі фігурки. Вони зображені таким чином, що голови розміщені у центрі, а нижня частина тулуба на периферії. Голови утворюють спільний для всіх богинь ромб. 3 символіки праміфу ми знаємо, що голови богинь передають небо. Отже, суцільний ромб у центрі символізує небо, а нижні частини фігур символізують дві інші «жіночі» сфери Космосу - сферу життя і підземелля. Це доцентричне моделювання Космосу, при якому земля зображається на периферії, а небо в центрі.

Для нас цей малюнок важливий тому, що в орнаментах жіночих сорочок Поділля зустрічаємо цілком аналогічну структуру. Так, цей візерунок (мал. 8.) утворений з ромбу, в якому розміщено чотири фігурки богинь. При цьому вони розміщені таким чином, що голови в центрі утворюють спільний ромбик, а умовні сідниці знаходяться на перифеpiї. Тут маємо повну збіжність зі структурами архаїчної символіки (мал. 7).

Висновки. Отже, в орнаментах ми виділили три структури, які аналогічні структурам архаїчної символіки. Це тричленна структура Богині-Космосу, структура двох богинь зі спільними сідницями і двадцятивосьмичленна структура, що моделює об'ємний Космос. Розглянуті структури не вичерпують наявних структур архаїчної символіки і традиційних народних орнаментів. Для нас важливо було показати, що методом проникнення в семантику орнаментів є метод виділення структур, спільних для архаїчної символіки та орнаментів.

\section{Література}

1. Голан А. Миф и символ. (2-е изд.). Москва: Русслит, 1994.

2. Кара-Васильєва Т. Геометричний орнамент української вишивки та сучасна його інтерпретація. IV французько-українська археологічна конференція «Геометричне мистецтво від преісторії до сучасності». Київ, 2015.

3. Причепій $€$. М. Дві богині в архаїчній символіці та в орнаментах народних рушників // Культурологічна думка. № 11. 2017.

4. Причепій $€$. М. Образ «богині-оленя» у геометричних орнаментах жіночих сорочок Поділля. Культурологічна думка № 16. 2019. С. 110-127. DOI: https://doi.org/10.37627/2311-9489-16-2019-2.110127

5. Gimbutas M. The Language of Goddess. (1st edition). New York: Thames \& Hudson, February 2001.

\section{References}

1. Golan A. My`f y` sy`mvol. (2-e y`zd.). Moskva: Russly`t, 1994.

2. Kara-Vasy `l 'yeva T. Geometry `chny ‘j ornament ukrayins `koyi vy`shy`vky` ta suchasna jogo interpretaciya. IV franczuz `ko-ukrayins `ka arxeologichna konferenciya «Geometry`chne my`stecztvo vid preistoriyi do suchasnosti». Ky`yiv, 2015.

3. Pry`chepij Ye. M. Dvi bogy`ni v arxayichnij sy`mvolici ta v ornamentax

narodny ‘x rushny`kiv // Kul `turologichna dumka. \# 11. 2017.

4. Pry`chepij Ye. M. Obraz «bogy`ni-olenya» u geometry`chny`x ornamentax zhinochy`x sorochok Podillya. Kul turologichna dumka \# 16. 2019. S. 110-127.

DOI: https://doi.org/10.37627/2311-9489-16-2019-2.110-127

5. Gimbutas M. The Language of Goddess. (1st edition). New York: Thames \& Hudson, February 2001. 
Малюнки подані за джерелами:

1. Gimbutas, M. (February 2001). The Language of Goddess. (1st edition). New York: Thames \& Hudson. (мал. 2; 5).

2. Архів автора (мал. 6).

3. Булгакова-Ситник Л. Подільська народна вишивка: Етнографічний аспект. (з іл.). О. Козакевич (ред.). Львів: НАН України, Інститут народознавства, 2005. (мал. 4; 8).

4. Голан А. Миф и символ. 2-е изд. с ил. Москва: Русслит, 1994 (мал. 3; 7).

5. Мифы народов мира: Энциклопедия: В 2-х т. 2-е изд. - М.: Большая Рос. Энцикл.: Олимп, 1998. (мал.1)

1.Author Archive: (fig. 6)

\section{Illustrations are taken from:}

2. Bulhakova-Sytnyk, L. (2005). Podilska narodna vyshyvka: Etnohrafichnyi aspect [Podolian Folk Embroidery: Ethnographic aspect]. O. Kozakevych (Ed.). Lviv: NAN Ukrainy, Instytut narodoznavstva. (in Ukrainian) (fig. 4, 8)

3. Gimbutas, M. (2001, February). The Language of Goddess. (1st edition). New York: Thames \& Hudson. (in English) (fig. 2, 5)

4. Golan, A. (1994). Mif i simvol [Myth and Symbol]. (2nd edition). Moscow: Russlit. (in Russian) (fig. 3, 7) 5 Mify narodov mira.: Enciklopedija (1998): W 2 т. /- 2-e izd/. - M.: Bolshaj Ros. Encikl.: Ollimp, (in Russian) (fig.1) Цей текст англійською не перевіряла — Л. Суміна

\section{Prychepii Y.}

Structural research method of semantics of geometrical ornaments

The thesis according to which semantics of geometrical ornaments is lost is denied. The author suggests applying the structures inherent in archaic symbolics at the analysis of these ornaments. In article it is allocated three-membered structure of the Goddess in ancient symbolics and display of this structure and its variants in geometrical ornaments of female shirts of Podolia is shown. The analysis has shown that the geometrical ornament has kept the semantics and it is possible to penetrate into it, using structures of primitive mythological representations.

Keywords: structures, a geometrical ornament, semantics of an ornament.

\section{Причепий Е. Н.}

\section{Структурный метод исследования семантики геометрических орнаментов}

Опровергается тезис, согласно которому семантика геометрических орнаментов утеряна. Автор предлагает применять при анализе этих орнаментов структуры, присущие архаической символике. В статье выделена трехчленная структура Богини в древней символике и показано отображение этой структуры и ее вариантов в геометрических орнаментах женских сорочек Подолья. Из анализа следует, что геометрический орнамент сохранил свою семантику и в нее можно проникнуть, используя структуры первобытных мифологических представлений. Ключевые слова: структуры, геометрический орнамент, семантика орнамента. 